\title{
ACPD
}

$15,11111-11141,2015$

\section{Heavy air pollution episodes in Beijing during January 2013: inorganic ion chemistry and source analysis using Highly Time-Resolved Measurements in an urban site}

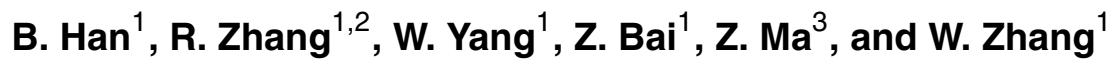

${ }^{1}$ State Key Laboratory of Environmental Criteria and Risk Assessment, Chinese Research Academy of Environmental Sciences, Beijing, China

${ }^{2}$ Beijing Municipal Research Institute of Environmental Protection, Beijing, China

${ }^{3}$ Institute of Urban Meteorology, China Meteorological Administration, Beijing, China

Received: 11 March 2015 - Accepted: 17 March 2015 - Published: 15 April 2015

Correspondence to: Z. Bai (baizp@ craes.org.cn)

Published by Copernicus Publications on behalf of the European Geosciences Union.

Heavy air pollution in Beijing

B. Han et al.

\section{Title Page}

Abstract

Conclusions

Tables

14

4

Back

Full Screen / Esc

Printer-friendly Version

Interactive Discussion 


\section{Abstract}

Heavy air pollution episodes occurred in Beijing in January 2013 attracted intensively attention around the whole world. During this period, the authors conducted highly time-resolved measurements of water soluble ions associated with $\mathrm{PM}_{2.5}$ at an urban 5 site, and attempted to distinguish the ion chemistry and potential sources. In this study, hourly mean concentrations of $\mathrm{Cl}^{-}, \mathrm{NO}_{3}^{-}, \mathrm{SO}_{4}^{2-}, \mathrm{Na}^{+}, \mathrm{NH}_{4}^{+}, \mathrm{K}^{+}, \mathrm{Mg}^{2+}$ and $\mathrm{Ca}^{2+}$ were measured during the air pollution episode in January 2013, and the ions were found to exist mainly in the form of $\left(\mathrm{NH}_{4}\right)_{2} \mathrm{SO}_{4}, \mathrm{NH}_{4} \mathrm{NO}_{3}, \mathrm{NaCl}$ and $\mathrm{KCl}$ in aerosol particles by correlation and linear analysis. $\mathrm{SO}_{4}^{2-}$ and $\mathrm{NO}_{3}^{-}$were observed peak concentrations 10 in 10-15, 18-20, 21-24, and 26-30 January during this monitoring campaign. The percentage of $\mathrm{SO}_{4}^{2-}$ and $\mathrm{NH}_{4}^{+}$in total ions concentrations exhibited an increasing trend with the enhancement of $\mathrm{PM}_{2.5}$ concentration, indicating high concentrations of $\mathrm{SO}_{4}^{2-}$ and $\mathrm{NH}_{4}^{+}$had played important roles in the formation of air pollution episodes. Ratio of $\left[\mathrm{NO}_{3}^{-}\right] /\left[\mathrm{SO}_{4}^{2-}\right]$ was calculated, finding the sources of $\mathrm{SO}_{4}^{2-}$ would contribute more to the 15 formation of $\mathrm{PM}_{2.5}$ than mobile sources. Diurnal variations of $\mathrm{SO}_{4}^{2-}, \mathrm{NO}_{3}^{-}, \mathrm{NH}_{4}^{+}$were examined, and all of them exhibited similar pattern with high concentration in night and relative low level at daytime. Emission from coal combustion, remote transportation at night or impact of meteorological was likely to be responsible for the high level of $\mathrm{SO}_{4}^{2-}$, $\mathrm{NH}_{4}^{+}$and $\mathrm{NO}_{3}^{-}$. Potential sources were identified by applying PMF. Secondary nitrate, 20 secondary sulfate, coal combustion and biomass burning, as well as fugitive dust were considered as the major contributors to total ions.

\section{Introduction}

As the capital of China, Beijing $\left(39.9^{\circ} \mathrm{N}, 116.4^{\circ} \mathrm{E}\right)$ has more than 20 million inhabitants distributed over $16800 \mathrm{~km}^{2}$. The city has been facing serious air pollution. During 25 the past two decades, Beijing experienced a rapid increase and development in en-

\section{ACPD}

15, 11111-11141, 2015

Heavy air pollution in Beijing

B. Han et al.

Title Page

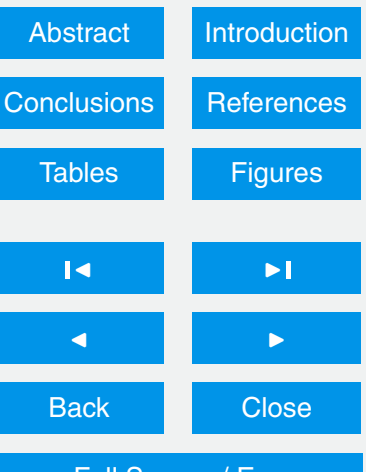

Full Screen / Esc

Printer-friendly Version

Interactive Discussion 
ergy consumption, vehicle quantities and urban expansion, plus the fugitive dust from surrounding soil or constructive activities.

Since 2000, air pollution control measures have been designed and taken to reduce local emission and improve air quality. However, after 2008 Olympic Games, the 5 regional pollution and visibility in the whole area has become worsen (Zhang et al., 2010) and serious air pollution episodes occurred frequently (Cao et al., 2012; Huang et al., 2010; Sun et al., 2013; Wang et al., 2009). High concentration of $\mathrm{PM}_{2.5}$ was believed to be largely responsible for the deterioration of air quality and visibility. With the implementation of China's new National Ambient Air Quality Standard for $\mathrm{PM}_{2.5}$ in 10 2012, more challenges arose to improve air quality in megacities (Hu et al., 2014).

Some previous studies found secondary inorganic aerosol (SIA), such as sulfate, nitrate and ammonium were the dominant ions in atmospheric $\mathrm{PM}_{2.5}$ of Beijing (Cao et al., 2012; Duan et al., 2003; Pathak et al., 2009; Yao et al., 2002). These components have effects on the hygroscopicity and acidity of aerosol, which are important factors 15 in influencing aerosol-phase chemistry and uptake of gaseous species by particles (Ocskay et al., 2006; Xue et al., 2011; Shon et al., 2012). He et al. (2001) and Ye et al. (2003) reported $\mathrm{SO}_{4}^{2-}, \mathrm{NO}_{3}^{-}$, and $\mathrm{NH}_{4}^{+}$accounted for about one-third of the total $\mathrm{PM}_{2.5}$ mass in Shanghai and Beijing. Yao et al. (2002) investigated the formation of $\mathrm{SO}_{4}^{2-}$ and $\mathrm{NO}_{3}^{-}$in $\mathrm{PM}_{2.5}$ in understanding the origin of these species. They found that 20 a large part of these species might be formed through the direct emissions of $\mathrm{SO}_{2}$, $\mathrm{NO}_{x}$, and $\mathrm{NH}_{3}$. Wang et al. (2005) collected daily $\mathrm{PM}_{2.5}$ aerosol samples at five sites in Beijing for a 3 year period from 2001 to 2003 , and analyzed concentrations of the watersoluble ions, finding that the inorganic ions existed mainly in the form of $\left(\mathrm{NH}_{4}\right)_{2} \mathrm{SO}_{4}$, $\mathrm{NH}_{4} \mathrm{NO}_{3}, \mathrm{NaCl}, \mathrm{KCl}$, and $\mathrm{CaCl}_{2}$ in aerosol particles. Zhang et al. (2013) collected daily $25 \mathrm{PM}_{2.5}$ samples between April 2009 and January 2010 at Beijing, finding $\mathrm{SO}_{4}^{2-}$ ranked the highest among the water-soluble ions analyzed, with an annual mean of $13.6 \pm$ $12.4{\mu \mathrm{gm}^{-3}}$, followed by $\mathrm{NO}_{3}^{-}\left(11.3 \pm 10.8 \mu \mathrm{gm}^{-3}\right), \mathrm{NH}_{4}^{+}\left(6.9 \pm 7.1 \mu \mathrm{gm}^{-3}\right), \mathrm{Ca}^{2+}(1.6 \pm$ $\left.1.4 \mu \mathrm{gm}^{-3}\right), \mathrm{Cl}^{-}\left(1.4 \pm 2.2 \mu \mathrm{gm}^{-3}\right), \mathrm{K}^{+}\left(0.92 \pm 0.75 \mu \mathrm{gm}^{-3}\right), \mathrm{Na}^{+}\left(0.46 \pm 0.55 \mu \mathrm{gm}^{-3}\right)$, and $\mathrm{Mg}^{2+}\left(0.16 \pm 0.13 \mu \mathrm{gm}^{-3}\right)$.

\section{ACPD}

15, 11111-11141, 2015

Heavy air pollution in Beijing

B. Han et al.

Title Page

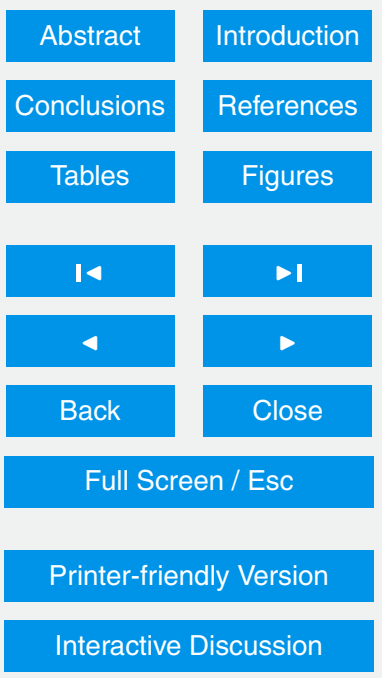

Interactive Discussion 
Most of previous studies used filter-based methods to collect PM samples with each sample covering hours to days. Such low temporal resolution data have limitations when used for investigating secondary aerosol formation and time evolution. Highly time-resolved measurements were considered to be helpful for a wide range of $\mathrm{PM}_{2.5}$ 5 components, including inorganic compounds. Data from the high resolution instruments offer significant advantages over traditional $24 \mathrm{~h}$ integrated filter-based measurements (Vedantham et al., 2014). To investigate the impacts of control measures and regional transport in 2008 Olympic Games, Gao et al. (2013) conducted highly time-resolved measurements of $\mathrm{SO}_{4}^{2-}, \mathrm{NO}_{3}^{-}$, and $\mathrm{NH}_{4}^{+}$in $\mathrm{PM}_{2.5}$ simultaneously at an urban site and 10 a downwind rural site in Beijing during the 2008 Olympics. The mean concentrations of $\mathrm{SO}_{4}^{2-}, \mathrm{NO}_{3}^{-}$, and $\mathrm{NH}_{4}^{+}$were $18.23,9.47$, and $9.70 \mu \mathrm{gm}^{-3}$, respectively, at the rural site and $20.74,8.83$, and $10.85 \mathrm{\mu g} \mathrm{m}^{-3}$, respectively, at the urban site. Hu et al. (2014) monitored hourly water-soluble inorganic ions in $\mathrm{PM}_{2.5}$ and gaseous precursors during June-November 2009 at an urban site in Beijing. The average mass concentration of 15 the total water-soluble ions was $44 \mathrm{\mu gm}^{-3}$, accounting for $38 \%$ of $\mathrm{PM}_{2.5} \cdot \mathrm{SO}_{4}^{2-}, \mathrm{NO}_{3}^{-}$, and $\mathrm{NH}_{4}^{+}$were dominant ions.

In the first beginning to 2013, Beijing's January air pollution episodes drew international media attention. Beijing, along with the rest of the mideastern region of China, experienced massive, severe air pollution episodes (Ouyang, 2013).

20 The high concentration of $\mathrm{PM}_{2.5}$ was believed to be largely responsible for the deterioration of air quality and visibility. Five haze pollution episodes were identified in the Beijing-Tianjin-Hebei area, with the two most severe episodes occurring during 9-15 and 25-31 January. During these two haze pollution episodes, the maximum hourly $\mathrm{PM}_{2.5}$ mass concentrations in Beijing were 680 and $530 \mu \mathrm{gm}^{-3}$, respectively (Wang 25 et al., 2014a). As urgent countermeasure, some industries and construction activities were suspended. Heavy air pollution episode also aroused some adverse health effects. The term "Beijing cough" has been in use since as early as the 1990s among foreigners, many of whom experienced chronic respiratory problems when they arrived in Beijing due to the city's dry and polluted air. But it did not become well-known un-

\section{ACPD}

$15,11111-11141,2015$

Heavy air pollution in Beijing

B. Han et al.

Title Page

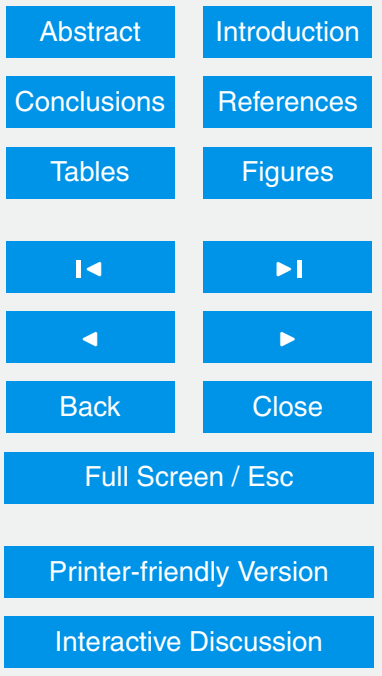


til recently, when more health problems directly attributable to the current heavy air pollution (Chen et al., 2013).

By now, there have been several studies related on the occurring of these heavy pollution episodes in Beijing. Wang et al. (2014a) and Ji et al. (2014) analyzed the mech5 anism for the formation of heavy pollution episode, concluding that the external cause of the severe haze episodes was the unusual atmospheric circulation, the depression of strong cold air activities and the very unfavorable dispersion due to geographical and meteorological conditions, and internal cause was the quick secondary transformation of primary gaseous pollutants to secondary aerosols. Secondary aerosol was 10 considered as one of the most important reasons of heavy air pollution episodes. Wang et al. (2014a) also revealed the two stage of aerosol growth. i.e. the "explosive growth" and "sustained growth". Huang et al. (2014) found anomalous meteorological conditions in 2013, which was different from the normal climatology from 2007-2012, were especially favorable for haze formation, and explained the formation mechanism of this episode in regard of aerosol chemistry based on the field measurement and meteorological analysis during the first half of January 2013. Zhang et al. (2014) achieved the similar conclusion that anomalous meteorology was found for this long-lasting air pollution episode, explaining about $2 / 3$ of the variance of daily visibility evolution. Model simulation indicated that regional transport played an important role in the formation of regional haze over the Beijing-Tianjin-Heibei area (Wang et al., 2014b)

To better understand the compositions of $\mathrm{PM}_{2.5}$ and their impact on air quality in the heavy air pollution episodes during January 2013 , this study analyzed the highly time-resolved measurements of inorganic ions associated with $\mathrm{PM}_{2.5}$, and investigated the characteristics of aerosol inorganic ions, major chemical forms, as well as potential sources. Different from previous studies which paid close attention to meteorological analysis, this paper mainly focused on specific ion compositions, which was considered as one of the major contributor to air pollution episode, and had an in-deep discussion on their role in forming the episode. The paper will help us have a more comprehensive understanding of air pollution episode in Beijing.

\section{ACPD}

15, 11111-11141, 2015
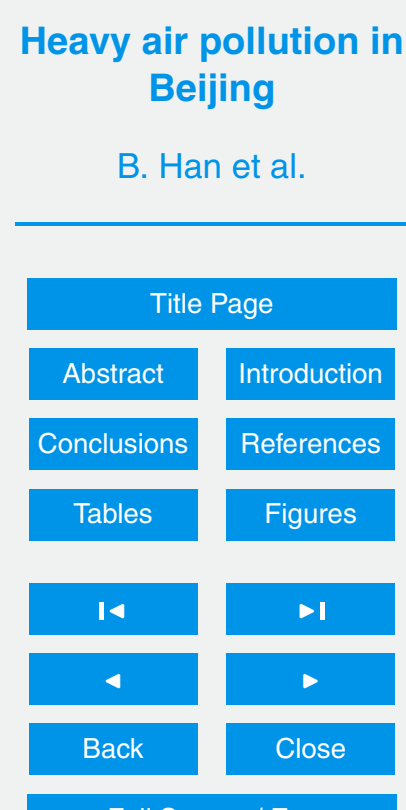

Full Screen / Esc

Printer-friendly Version

Interactive Discussion 


\section{Experimental}

\subsection{Sampling sites and meteorological conditions}

ACPD

The field campaign was conducted in the January 2013, and the sampling site was on the rooftop of a building in the Chinese Research Academy of Environmental Sciences

5 (CRAES, $40^{\circ} 2^{\prime} 29.46^{\prime \prime} \mathrm{N}, 116^{\circ} 24^{\prime} 51.00^{\prime \prime} \mathrm{E}$ ), which is located outside the $4 \mathrm{~km}$ north of the 5th Ring Road and $15 \mathrm{~km}$ from the city center as shown in Fig. 1.

The wind rose of Beijing in January is depicted in Fig. 2, and the corresponding calm wind frequencies are listed in Table 1. Firstly, the prevailing wind directions (frequency higher than $10 \%)$ were SW (12.50\%), ENE (11.33\%), N (10.94\%) and WSW

$10(10.74 \%)$. Compared with the statistical results of Zhao et al. (2013) for 2009 and 2010, the frequency of WSW, SW and SSW were higher in this study. Su et al. (2004) concluded that southwest transport pathway was one of the three major pathways for outside pollutants being transported to Beijing. The CMAQ model simulation of secondary aerosols around Beijing in summer of 2003 by Liu et al. (2005) suggested that when wind from southern and southwestern directions prevails in Beijing, high concentrations of vapor and $\mathrm{NH}_{3}$ was brought in, which would enhanc the efficiency of the secondary aerosol production. Secondly, the average temperature in January 2013 $\left(-5.1^{\circ} \mathrm{C}\right)$ was lower than that in 2009 and $2010\left(-2.0^{\circ} \mathrm{C}\right)$ (Zhao et al., 2013). Lower temperature would lead to more demand for fossil fuel, and more air pollutants could be emitted. Thirdly, the calm wind frequency (6.64\%) was higher than that in 2009 and 2010 (3.21\%), which was perhaps an important reason for the air pollution episode in January 2013.

\subsection{Instruments}

The hourly concentrations of $\mathrm{Cl}^{-}, \mathrm{NO}_{3}^{-}, \mathrm{SO}_{4}^{2-}, \mathrm{Na}^{+}, \mathrm{NH}_{4}^{+}, \mathrm{K}^{+}, \mathrm{Mg}^{2+}$ and $\mathrm{Ca}^{2+}$ associated with $\mathrm{PM}_{2.5}$ were simultaneously measured by an ambient ion monitor (Model URG 9000B, URG Corporation, USA). This instrument draws air in through a $\mathrm{PM}_{2.5}$

Heavy air pollution in Beijing

B. Han et al.

\section{Title Page}

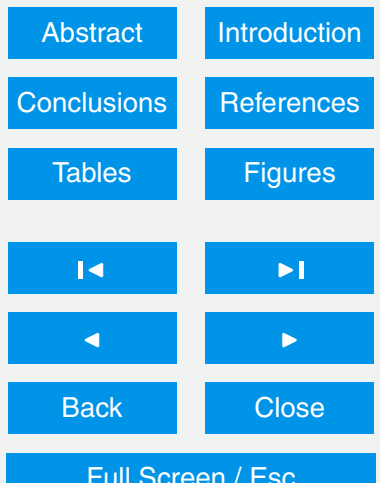

Full Screen / Esc

Printer-friendly Version

Interactive Discussion 
sharp-cut cyclone at a volumetric-flow controlled rate of $3 \mathrm{Lmin}^{-1}$ to remove the larger particles from the air stream. Then the air stream is drawn through a liquid diffusion denuder where water-soluble acid gases (e.g., $\mathrm{SO}_{2}, \mathrm{NH}_{3}$, and $\mathrm{HNO}_{3}$ ) are removed. In order to achieve high collection efficiencies, the particles-laden air stream next enters

5 an aerosol super-saturation chamber to enhance particle growth. An inertial particle separator collects these enlarged particles, which are dissolved in water solution and then injected into the ion chromatograph. The detection limits of ions were shown in Table 2.

Hourly concentrations of $\mathrm{PM}_{2.5}$ were obtained from Chaoyang Meteorological Bureau, which is $10 \mathrm{~km}$ away from the CRAES sampling site.

\subsection{Data analysis}

Data were analyzed using SPSS 17.0 for Windows (SPSS Inc., 2008) for the correlation analysis and linear regression. EPA PMF 4.2 (USEPA, 2011) was applied to identify the potential contributors to the ion species. A detailed introduction to Positive Matrix 15 Factorization (PMF) is shown in the Supplement.

\section{Results and discussion}

\subsection{Characterizations of ionic species}

Water-soluble ions comprise a large part of aerosol particles and play an important role in the atmosphere. $\mathrm{Na}^{+}, \mathrm{Mg}^{2+}$, and $\mathrm{Ca}^{2+}$ are mainly from crustal sources, such as re-suspended road dust, soil dust, and construction dust, and $\mathrm{SO}_{4}^{2-}, \mathrm{NO}_{3}^{-}$, and $\mathrm{NH}_{4}^{+}$ represent the secondary pollution sources from the transformation of their precursors of $\mathrm{NH}_{3}, \mathrm{SO}_{2}$ and $\mathrm{NO}_{\mathrm{x}}$ (Wang et al., 2005). $\mathrm{Cl}^{-}$is usually considered to be from coal combustion (He et al., 2001), and $\mathrm{K}^{+}$is from biomass burning (Duan et al., 2004).
ACPD

$15,11111-11141,2015$

Heavy air pollution in Beijing

B. Han et al.

Title Page
Abstract

Conclusions

Tables

14

4

Back
Introduction

References

Figures

>I

>

Close
Full Screen / Esc

Printer-friendly Version

Interactive Discussion 
The concentrations of ionic species in the whole sampling period were shown in Table 3. Hourly concentrations of individual ions from AIM measurements varied significantly in a broad range. Emission intensities of gaseous precursors, oxidation or conversion rate, local atmospheric mixing, and regional transport all would affect their concentration levels (Hu et al., 2014).

Wang et al. (2014a) reported that five air pollution episodes were identified in the Beijing-Tianjin-Hebei (Jing-Jin-Ji) area in this time period, and the two most severe episodes occurred during 9-15 and 25-31 January. This study also analyzed the continuous variations of ions in Fig. 3, finding peak values of $\mathrm{SO}_{4}^{2-}, \mathrm{NO}_{3}^{-}$and $\mathrm{Cl}^{-}$were 10 observed on four periods: $10-15,18-20,21-24$, and 26-30 January. $\mathrm{NH}_{4}^{+}$and $\mathrm{K}^{+}$ had only peak concentrations during 10-15 January. Concentrations of $\mathrm{Na}^{+}, \mathrm{Ca}^{2+}$ and $\mathrm{Mg}^{2+}$ showed no significant variations before 28 January. In the last several days, the concentrations of $\mathrm{Ca}^{2+}$ and $\mathrm{Mg}^{2+}$ decreased dramatically. Most constructive activities related with the emission of $\mathrm{Ca}^{2+}$ and $\mathrm{Mg}^{2+}$ were suspended by government during 15 this episode. This would perhaps be the reason of lower concentrations of $\mathrm{Ca}^{2+}$ and $\mathrm{Mg}^{2+}$ after 28 January.

To better understand the ion species characterizations in January 2013 , the main ion concentrations measured by manual sampling in the winter of Beijing from other study were summarized in Table 4 . We can find that the concentrations of $\mathrm{SO}_{4}^{2-}, \mathrm{NO}_{3}^{-}, \mathrm{Cl}^{-}$ 20 and $\mathrm{NH}_{4}^{+}$were comparable in different studies.

Huang et al. (2014) collected $\mathrm{PM}_{2.5}$ samples during 4-9 January (light air pollution) and 10-15 January (heavy air pollution), and analyzed daily concentrations of ions. We calculated the mean ions concentrations during corresponding time periods as shown in Table 5. The concentrations of $\mathrm{Cl}^{-}, \mathrm{NO}_{3}^{-}, \mathrm{SO}_{4}^{2-}$ and $\mathrm{NH}_{4}^{+}$in these two studies are comparable, except the $\mathrm{NH}_{4}^{+}$during light air pollution period (4-9 January). Large differences were observed for some ions with relatively low levels, such as $\mathrm{Na}^{+}, \mathrm{K}^{+}$, $\mathrm{Mg}^{2+}, \mathrm{Ca}^{2+}$.

Chinese Ministry of Environmental Protection promulgated "Technical Regulation on Ambient Air Quality Index (on trial)" in 2012, and regulated the AQI values and corre-

\section{ACPD}

15, 11111-11141, 2015

Heavy air pollution in Beijing

B. Han et al.

Title Page

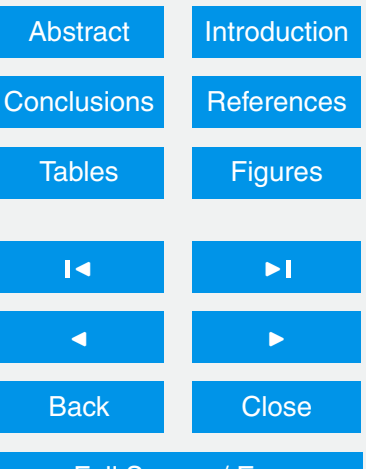

Full Screen / Esc

Printer-friendly Version

Interactive Discussion 
sponding concentrations of air pollutants. The regulation divided the daily concentrations of $\mathrm{PM}_{2.5}$ into six classes: 0-35, 35-75, 75-115, 115-150, 150-250 and larger than $250 \mathrm{\mu g} \mathrm{m}^{-3}$, corresponding AQI as follows: 0-50 (excellent), 51-100 (good), 101150 (light pollution), 151-200 (medium pollution), 201-300 (heavy pollution) and more 5 than 300 (severe pollution). According to the $\mathrm{PM}_{2.5}$ concentration classification, this study divided the ions concentrations into six categories and compared their distribution trend in Fig. 4. Except $\mathrm{Mg}^{2+}$ and $\mathrm{Ca}^{2+}$, all ions concentrations showed an increasing trend with the deterioration of $\mathrm{PM}_{2.5}$ pollution, indicating the ion species (except $\mathrm{Mg}^{2+}$ and $\mathrm{Ca}^{2+}$ ) contributed to the increase of $\mathrm{PM}_{2.5}$ concentration.

10 To further investigate the relative abundance variation trend, percentage of ion species in different $\mathrm{PM}_{2.5}$ concentration ranges were calculated as shown in Fig. 5. $\mathrm{Cl}^{-}, \mathrm{NO}_{3}^{-}, \mathrm{Na}^{+}, \mathrm{K}^{+}, \mathrm{Mg}^{2+}$ and $\mathrm{Ca}^{2+}$ showed a declining trend along with the increase of $\mathrm{PM}_{2.5}$ levels, while $\mathrm{SO}_{4}^{2-}$ and $\mathrm{NH}_{4}^{+}$took up increasing proportions of total ions (the increasing of $\mathrm{NH}_{4}^{+}$abundance was not significant, from $12.7 \%$ under the $\mathrm{PM}_{2.5}$ con15 centration less than $35 \mathrm{\mu g} \mathrm{m}^{-3}$ to $18.5 \%$ under the $\mathrm{PM}_{2.5}$ concentration larger than $250 \mathrm{\mu g} \mathrm{m}^{-3}$ ). The different variations of species percentage in total ions indicate that $\mathrm{SO}_{4}^{2-}$ and $\mathrm{NH}_{4}^{+}$may contribute more to the $\mathrm{PM}_{2.5}$ pollution. This result is similar with the conclusion of Wang et al. (2014a), who considered the increasing proportion of sulfate enhanced particle hygroscopicity and thereby accelerating formation of the haze pollution.

\subsection{Ratio of $\left[\mathrm{NO}_{3}^{-}\right] /\left[\mathrm{SO}_{4}^{2-}\right]$}

The mass ratio of $\left[\mathrm{NO}_{3}^{-}\right] /\left[\mathrm{SO}_{4}^{2-}\right]$ has been used as an indicator of the relative importance of stationary vs. mobile sources of sulfur and nitrogen in the atmosphere. Higher $\left[\mathrm{NO}_{3}^{-}\right] /\left[\mathrm{SO}_{4}^{2-}\right]$ mass ratios indicate the predominance of mobile sources over stationary

The average mass ratio of $\left[\mathrm{NO}_{3}^{-}\right] /\left[\mathrm{SO}_{4}^{2-}\right]$ during the observation period was $0.68 \pm$ 0.44 , which was comparable with the results of Wang et al. (2014a), but higher than the

ACPD

$15,11111-11141,2015$

Heavy air pollution in Beijing

B. Han et al.

Title Page

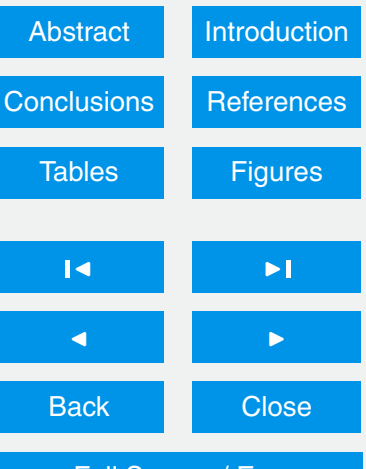

Full Screen / Esc

Printer-friendly Version

Interactive Discussion 
value measured during the winters of 2001-2003 in Beijing (0.49). Wang et al. (2005) suggested that the contribution of mobile sources (e.g., motor vehicles) increased in Beijing, in accord with the adjustment of the energy structure in recent years.

The $\left[\mathrm{NO}_{3}^{-}\right] /\left[\mathrm{SO}_{4}^{2-}\right]$ ratio was also classified according to the $\mathrm{PM}_{2.5}$ concentration 5 ranges. As shown in Fig. 6 , we can find that the $\left[\mathrm{NO}_{3}^{-}\right] /\left[\mathrm{SO}_{4}^{2-}\right]$ ratio decrease with the

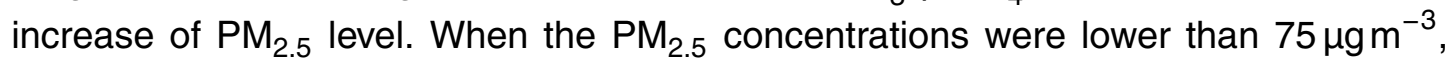
the ratio were larger than 1 , indicating predominance of mobile source over stationary source of pollutants. When $\mathrm{PM}_{2.5}$ concentration increased, the stationary sources would contribute more pollutants than mobile sources. The results also confirmed that ${ }_{10} \mathrm{SO}_{4}^{2-}$ was one of the most important compositions which contributed to the $\mathrm{PM}_{2.5}$ heavy pollution.

\subsection{Diurnal variation}

The diurnal variations of ion species in $\mathrm{PM}_{2.5}$ in the sampling period were shown in Fig. 7. On the whole, $\mathrm{SO}_{4}^{2-}, \mathrm{NO}_{3}^{-}, \mathrm{Cl}^{-}, \mathrm{K}^{+}$and $\mathrm{NH}_{4}^{+}$exhibited similar diurnal patterns with a broad nighttime maximum and a relatively low concentration at daytime, while the variations of $\mathrm{Na}^{+}, \mathrm{Mg}^{2+}$ and $\mathrm{Ca}^{2+}$ were small. Compared with another highly resolved measurements for ion species at the same site during summer of 2008 (Gao et al., 2013), the diurnal cycle of $\mathrm{SO}_{4}^{2-}$ in this study was completely opposite, i.e., the highest concentration of $\mathrm{SO}_{4}^{2-}$ occurred at daytime and the lowest at night during summer campaign of 2008. Also, for some ions, such as $\mathrm{SO}_{4}^{2-}, \mathrm{Cl}^{-}$and $\mathrm{K}^{+}$, high levels at night and low concentrations at daytime could be the characterizations of coal combustion. The sampling site is located outside the 5th ring of Beijing, and there still exists considerable coal combustion boilers for domestic heating. The emission from these coal combustion facilities would be one of the important reasons that led to the diurnal 25 variations.

Gao et al. (2013) found the $\mathrm{SO}_{4}^{2-}$ concentrations in summer rapidly increased from the early morning to the late afternoon synchronously with the enhancement of solar

Heavy air pollution in Beijing

B. Han et al.

Title Page

Conclusions

References

Tables

Figures

14

$>1$

4

Back

Close

Full Screen / Esc

Printer-friendly Version

Interactive Discussion 
radiation and the $\mathrm{O}_{3}$ and $\mathrm{SO}_{2}$ concentrations. In this study, the $\mathrm{O}_{3}$ concentration was low, especially in the pollution episodes $\left(<15 \mu \mathrm{g} \mathrm{m}^{-3}\right)$ (Wang et al., 2014a). Such low $\mathrm{O}_{3}$ levels cannot supply enough oxidizing capacity in the atmosphere; therefore, other oxidation reactions, regional transport at night or the impact of meteorological may also 5 be responsible for the high levels of $\mathrm{SO}_{4}^{2-}, \mathrm{NH}_{4}^{+}$and $\mathrm{NO}_{3}^{-}$.

\subsection{The speciation of major ions}

The chemical forms of those major ions, i.e. $\mathrm{SO}_{4}^{2-}, \mathrm{NO}_{3}^{-}, \mathrm{Cl}, \mathrm{NH}_{4}^{+}, \mathrm{Ca}^{2+}$, and $\mathrm{K}^{+}$, in aerosols in Beijing were identified by bivariate correlations. Verma et al. (2010) and Wang et al. (2005) used bivariate correlations to identify the possible chemical forms of ions in $\mathrm{PM}_{2.5}$. Since concentrations of all the ions are not normally distributed (k-s test, $p<0.05)$, Spearman Correlation analysis was applied. Table 5 showed the correlation coefficients among these major ions.

Ammonia is an important alkaline gas in the atmosphere. Ammonia in air is neutralized first by $\mathrm{H}_{2} \mathrm{SO}_{4}$ to form $\left(\mathrm{NH}_{4}\right)_{2} \mathrm{SO}_{4}$ or $\mathrm{NH}_{4} \mathrm{HSO}_{4}$, and then the remaining is neutralized by reaction with $\mathrm{HNO}_{3}$ to form $\mathrm{NH}_{4}-\mathrm{NO}_{3}$.

In this study, among all cations, $\mathrm{NH}_{4}^{+}$was highly significantly correlated with $\mathrm{NO}_{3}^{-}$ and $\mathrm{SO}_{4}^{2-}$ as shown in Table 6 . The slope of the regression between $\mathrm{NH}_{4}^{+}$and $\mathrm{SO}_{4}^{2-}$ ( $\mu$ eq vs. $\mu \mathrm{eq}$ ) for the whole data set was 1.33, indicating the complete neutralization of $\mathrm{SO}_{4}^{2-}$ by $\mathrm{NH}_{4}^{+}$, and suggested that $\left(\mathrm{NH}_{4}\right)_{2} \mathrm{SO}_{4}$, instead of $\mathrm{NH}_{4} \mathrm{HSO}_{4}$, was the major 20 species formed by $\mathrm{SO}_{4}^{2-}$ and $\mathrm{NH}_{4}^{+}$. Moreover, the slope between $\mathrm{NH}_{4}^{+}$and the sum of $\mathrm{SO}_{4}^{2-}$ and $\mathrm{NO}_{3}^{-}$( $\mu$ eq vs. $\mu$ eq) was 0.99 , further revealing $\mathrm{NH}_{4}^{+}$completely neutralized by both $\mathrm{SO}_{4}^{2-}$ and $\mathrm{NO}_{3}^{-}$. Thus only $\mathrm{Cl}^{-}$can supply negative charge to balance the $\mathrm{Na}^{+}$, $\mathrm{K}^{+}$. Considering the correlation coefficients of $\mathrm{Cl}^{-}$between $\mathrm{Na}^{+}, \mathrm{K}^{+}$, were comparable, the mixture of $\mathrm{NaCl}$ and $\mathrm{KCl}$ were likely to be the major form of ions $\left(\mathrm{NH}_{4}\right)_{2} \mathrm{SO}_{4}$ and $25 \mathrm{NH}_{4} \mathrm{NO}_{3}$.
ACPD

15, 11111-11141, 2015

Heavy air pollution in Beijing

B. Han et al.

Title Page

Abstract

Introduction

Conclusions

References

Tables

Figures

$1<$

$>1$

4

Back

$>$

Close

Full Screen / Esc

Printer-friendly Version

Interactive Discussion 


\subsection{Source analysis}

The mass concentrations of all ions species were input into EPA PMF 4.2 model to identify the potential sources. Four factors were isolated, representing potential sources, including secondary nitrate, secondary sulfate, coal combustion and biomass burning,

5 and fugitive dust. The factor profiles of $\mathrm{PM}_{2.5}$ bound ion species at the monitoring site are shown in Fig. 8.

Factor 1 and factor 2 were considered as secondary nitrate and sulfate, with high loading of $\mathrm{NO}_{3}^{-}$and $\mathrm{NH}_{4}^{+}$in factor 1 , as well as $\mathrm{SO}_{4}^{2-}$ and $\mathrm{NH}_{4}^{+}$in factor $2 . \mathrm{NO}_{3}^{-}$is mainly converted from ambient $\mathrm{NO}_{\mathrm{x}}$, which is emitted by both vehicle exhaust and fossil fuel combustion. The precursor of aerosol $\mathrm{SO}_{4}^{2-}$ is $\mathrm{SO}_{2}$, which may originate from biomass burning and fossil fuel combustion. $\mathrm{Cl}^{-}$and $\mathrm{K}^{+}$were found to be the main contributors to factor 3 , originating mainly from coal and biomass combustion. Factor 4 is identified as fugitive dust, such as soil dust, constructive dust, and paved or unpaved road dust, including high contributions of $\mathrm{Ca}^{2+}$ and $\mathrm{Mg}^{2+}$.

The factor contributions to the ion concentrations are illustrated in Fig. 9. Factors 1 and 2 were the biggest contributors to $\mathrm{NO}_{3}^{-}$and $\mathrm{SO}_{4}^{2-}$, respectively. Both factors also comparably contribute to the concentration of $\mathrm{NH}_{4}^{+}$. Factor 3 was the main source for $\mathrm{Cl}^{-}$and $\mathrm{K}^{+}$, while factors 1 and 2 also took some portions for $\mathrm{Cl}^{-}$and $\mathrm{K}^{+}$, respectively. $\mathrm{Na}^{+}, \mathrm{Mg}^{2+}$ and $\mathrm{Ca}^{2+}$ were mostly contributed by factor 4 .

\section{Conclusions}

In this study, we reported in-situ measurements of water-soluble inorganic ions associated with $\mathrm{PM}_{2.5}$ at an urban site of Beijing during the air pollution episode in January 2013. The hourly concentrations of $\mathrm{Cl}^{-}, \mathrm{NO}_{3}^{-}, \mathrm{SO}_{4}^{2-}, \mathrm{Na}^{+}, \mathrm{NH}_{4}^{+}, \mathrm{K}^{+}, \mathrm{Mg}^{2+}$ and $\mathrm{Ca}^{2+}$ were measured.

25 Peak concentrations of the ions were observed in four periods $(10-15,18-20,21-$ 24, and 26-30 January). $\mathrm{SO}_{4}^{2-}$ and $\mathrm{NO}_{3}^{-}$exhibited high concentrations in three periods.

Heavy air pollution in Beijing

B. Han et al.

Title Page 
Meanwhile, the percentage of $\mathrm{SO}_{4}^{2-}$ in total ions concentrations kept an increasing trend with the enhancement of $\mathrm{PM}_{2.5}$ concentration, thus high concentrations of $\mathrm{SO}_{4}^{2-}$ and $\mathrm{NH}_{4}^{+}$can be considered as one of the main reasons of air pollution episodes. $\mathrm{NH}_{4}^{+}$also played an important role in the formation of $\mathrm{PM}_{2.5}$. Based on the correlation 5 analysis, the observed ions existed mainly in the form of $\left(\mathrm{NH}_{4}\right)_{2} \mathrm{SO}_{4}, \mathrm{NH}_{4} \mathrm{NO}_{3}, \mathrm{NaCl}$ and $\mathrm{KCl}$ in aerosol particles.

The ratio of $\left[\mathrm{NO}_{3}^{-}\right] /\left[\mathrm{SO}_{4}^{2-}\right]$ also proved the role of $\mathrm{SO}_{4}^{2-}$ in the air pollution episodes. With the aggravation of air quality, the $\left[\mathrm{NO}_{3}^{-}\right] /\left[\mathrm{SO}_{4}^{2-}\right]$ displayed a decreasing trend, indicating the $\mathrm{SO}_{2}$ emitters, such as some stationary sources, contributed more to $\mathrm{PM}_{2.5}$ aerosols formation, rather than mobile sources, which are considered as the sources of $\mathrm{NO}_{3}^{-}$.

Obvious diurnal variations of $\mathrm{SO}_{4}^{2-}, \mathrm{NO}_{3}^{-}, \mathrm{NH}_{4}^{+}$were observed. All of them exhibited similar patterns with high concentration in night and relatively low level at daytime. Considering the lack of strong oxidative atmosphere during monitoring period, pollutant 15 transport at night may be responsible for the high level of $\mathrm{SO}_{4}^{2-}, \mathrm{NH}_{4}^{+}$and $\mathrm{NO}_{3}^{-}$.

Potential sources were identified by applying PMF. Secondary nitrate, secondary sulfate, coal combustion and biomass burning, as well as fugitive dust were considered as the major contributors to total ions.

Acknowledgement. This study was funded by "National Basic Research Program of China" (Grants No. 2011CB503801) and Beijing Natural Science Foundation (8121002).

\section{References}

Arimoto, R., Duce, R. A., Savoie, D. L., Prospero, J. M., Talbot, R., Cullen, J. D., Tomza, U., Lewis, N. F., and Ray, B. J.: Relationships among aerosol constituents from Asia and the North Pacific during PEM-West A, J. Geophys. Res.-Atmos., 101, 2011-2023, doi:10.1029/95jd01071, 1996.

ACPD

15, 11111-11141, 2015

Heavy air pollution in Beijing

B. Han et al.

\section{Title Page}

Abstract

Introduction

Conclusions

References

Tables

Figures

14

$>1$

4

Back

$>$

Close

Full Screen / Esc

Printer-friendly Version

Interactive Discussion 
Cao, J.-J., Shen, Z.-X., Chow, J. C., Watson, J. G., Lee, S.-C., Tie, X.-X., Ho, K.-F., Wang, G.-H., and Han, Y.-M.: Winter and summer $\mathrm{PM}_{2.5}$ chemical compositions in fourteen Chinese cities, JAPCA J. Air Waste Ma., 62, 1214-1226, doi:10.1080/10962247.2012.701193, 2012.

Chen, R. J., Zhao, Z. H., and Kan, H. D.: Heavy smog and hospital visits in Beijing, China, Am. J. Resp. Crit. Care, 188, 1170-1171, 2013.

Duan, F. K., Liu, X. D., He, K. B., Lu, Y. Q., and Wang, L.: Atmospheric aerosol concentration level and chemical characteristics of water-soluble ionic species in wintertime in Beijing, China, J. Environ. Monitor., 5, 569-573, doi:10.1039/b303691j, 2003.

Duan, F. K., Liu, X. D., Yu, T., and Cachier, H.: Identification and estimate of biomass burning contribution to the urban aerosol organic carbon concentrations in Beijing, Atmos. Environ., 38, 1275-1282, doi:10.1016/j.atmosenv.2003.11.037, 2004.

Gao, X., Nie, W., Xue, L., Wang, T., Wang, X., Gao, R., Wang, W., Yuan, C., Gao, J., Ravi, K. P., Wang, J., and Zhang, Q.: Highly time-resolved measurements of secondary ions in $\mathrm{PM}_{2.5}$ during the 2008 Beijing Olympics: the impacts of control measures and regional transport, Aerosol Air Qual. Res., 13, 367-376, doi:10.4209/aaqr.2012.04.0083, 2013.

He, K., Yang, F., Ma, Y., Zhang, Q., Yao, X., Chan, C. K., Cadle, S., Chan, T., and Mulawa, P.: The characteristics of $\mathrm{PM}_{2.5}$ in Beijing, China, Atmos. Environ., 35, 4959-4970, doi:10.1016/S1352-2310(01)00301-6, 2001.

Hu, G., Zhang, Y., Sun, J., Zhang, L., Shen, X., Lin, W., and Yang, Y.: Variability, formation and acidity of water-soluble ions in $\mathrm{PM}_{2.5}$ in Beijing based on the semi-continuous observations, Atmos. Res., 145-146, 1-11, doi:10.1016/j.atmosres.2014.03.014, 2014.

Huang, K., Zhuang, G., Wang, Q., Fu, J. S., Lin, Y., Liu, T., Han, L., and Deng, C.: Extreme haze pollution in Beijing during January 2013: chemical characteristics, formation mechanism and role of fog processing, Atmos. Chem. Phys. Discuss., 14, 7517-7556, doi:10.5194/acpd-147517-2014, 2014.

Huang, X.-F., He, L.-Y., Hu, M., Canagaratna, M. R., Sun, Y., Zhang, Q., Zhu, T., Xue, L., Zeng, L.-W., Liu, X.-G., Zhang, Y.-H., Jayne, J. T., Ng, N. L., and Worsnop, D. R.: Highly timeresolved chemical characterization of atmospheric submicron particles during 2008 Beijing Olympic Games using an Aerodyne High-Resolution Aerosol Mass Spectrometer, Atmos.

30 Chem. Phys., 10, 8933-8945, doi:10.5194/acp-10-8933-2010, 2010.

Ji, D., Li, L., Wang, Y., Zhang, J., Cheng, M., Sun, Y., Liu, Z., Wang, L., Tang, G., Hu, B., Chao, N., Wen, T., and Miao, H.: The heaviest particulate air-pollution episodes occurred
ACPD

15, 11111-11141, 2015

Heavy air pollution in Beijing

B. Han et al.

Title Page

Abstract

Introduction

Conclusions

References

Tables

Figures

14

DI

4

Back

$>$

Close

Full Screen / Esc

Printer-friendly Version

Interactive Discussion 
in northern China in January 2013: insights gained from observation, Atmos. Environ., 92, 546-556, doi:10.1016/j.atmosenv.2014.04.048, 2014.

Liu, Y., Li, W. L., and Zhou, X. J.: Simulation of secondary aerosols over North China in summer, Sci. China Ser. D, 48, 185-195, doi:10.1360/05yd0405, 2005.

5 Ocskay, R., Salma, I., Wang, W., and Maenhaut, W.: Characterization and diurnal variation of size-resolved inorganic water-soluble ions at a rural background site, J. Environ. Monitor., 8, 300-306, doi:10.1039/b513915e, 2006.

Ouyang, Y.: China wakes up to the crisis of air pollution, The Lancet Respiratory Medicine, 1, 12, doi:10.1016/S2213-2600(12)70065-6, 2013.

10 Pathak, R. K., Wu, W. S., and Wang, T.: Summertime $\mathrm{PM}_{2.5}$ ionic species in four major cities of China: nitrate formation in an ammonia-deficient atmosphere, Atmos. Chem. Phys., 9, 1711-1722, doi:10.5194/acp-9-1711-2009, 2009.

Shon, Z.-H., Kim, K.-H., Song, S.-K., Jung, K., Kim, N.-J., and Lee, J.-B.: Relationship between water-soluble ions in $\mathrm{PM}_{2.5}$ and their precursor gases in Seoul megacity, Atmos. Environ., 59, 540-550, doi:10.1016/j.atmosenv.2012.04.033, 2012.

Su, F. Q., Gao, Q. X., Zhang, Z. G., Ren, Z. H., and Yang, X. X.: Transport pathways of pollutants from outside in atmosphere boundary layer (in Chinese with English abstract), Res. Environ. Sci., 17, 26-40, 2004.

Sun, Y. L., Wang, Z. F., Fu, P. Q., Yang, T., Jiang, Q., Dong, H. B., Li, J., and Jia, J. J.: Aerosol composition, sources and processes during wintertime in Beijing, China, Atmos. Chem. Phys., 13, 4577-4592, doi:10.5194/acp-13-4577-2013, 2013.

Vedantham, R., Landis, M. S., Olson, D., and Pancras, J. P.: Source identification of $\mathrm{PM}_{2.5}$ in Steubenville, Ohio using a hybrid method for highly time-resolved data, Environ. Sci. Technol., 48, 1718-1726, doi:10.1021/es402704n, 2014.

Verma, S. K., Deb, M. K., Suzuki, Y., and Tsai, Y. I.: Ion chemistry and source identification of coarse and fine aerosols in an urban area of eastern central India, Atmos. Res., 95, 65-76, doi:10.1016/j.atmosres.2009.08.008, 2010.

Wang, W., Primbs, T., Tao, S., and Simonich, S. L. M.: Atmospheric particulate matter pollution during the 2008 Beijing Olympics, Environ. Sci. Technol., 43, 6440-6440, 30 doi:10.1021/es901953s, 2009.

Wang, Y., Zhuang, G. S., Tang, A. H., Yuan, H., Sun, Y. L., Chen, S. A., and Zheng, A. H.: The ion chemistry and the source of $\mathrm{PM}_{2.5}$ aerosol in Beijing, Atmos. Environ., 39, 3771-3784, doi:10.1016/j.atmosenv.2005.03.013, 2005.

Heavy air pollution in Beijing

B. Han et al.

Title Page 
Wang, Y., Yao, L., Wang, L., Liu, Z., Ji, D., Tang, G., Zhang, J., Sun, Y., Hu, B., and Xin, J.: Mechanism for the formation of the January 2013 heavy haze pollution episode over central and eastern China, Sci. China Ser. D, 57, 14-25, doi:10.1007/s11430-013-4773-4, 2014a.

Wang, Z., Li, J., Wang, Z., Yang, W., Tang, X., Ge, B., Yan, P., Zhu, L., Chen, X., Chen, H.,

$5 \quad$ Wand, W., Li, J., Liu, B., Wang, X., Zhao, Y., Lu, N., and Su, D.: Modeling study of regional severe hazes over mid-eastern China in January 2013 and its implications on pollution prevention and control, Sci. China Ser. D, 57, 3-13, doi:10.1007/s11430-013-4793-0, 2014b.

Xue, J., Lau, A. K. H., and Yu, J. Z.: A study of acidity on $\mathrm{PM}_{2.5}$ in Hong Kong using online ionic chemical composition measurements, Atmos. Environ., 45, 7081-7088, doi:10.1016/j.atmosenv.2011.09.040, 2011.

Yao, X., Chan, C. K., Fang, M., Cadle, S., Chan, T., Mulawa, P., He, K., and Ye, B.: The watersoluble ionic composition of $\mathrm{PM}_{2.5}$ in Shanghai and Beijing, China, Atmos. Environ., 36, 4223-4234, doi:10.1016/S1352-2310(02)00342-4, 2002.

Ye, B., Ji, X., Yang, H., Yao, X., Chan, C. K., Cadle, S. H., Chan, T., and Mulawa, P. A.: Concen15 tration and chemical composition of $\mathrm{PM}_{2.5}$ in Shanghai for a 1-year period, Atmos. Environ., 37, 499-510, doi:10.1016/S1352-2310(02)00918-4, 2003.

Zhang, Q. H., Zhang, J. P., and Xue, H. W.: The challenge of improving visibility in Beijing, Atmos. Chem. Phys., 10, 7821-7827, doi:10.5194/acp-10-7821-2010, 2010.

Zhang, R., Jing, J., Tao, J., Hsu, S.-C., Wang, G., Cao, J., Lee, C. S. L., Zhu, L., Chen, Z., Zhao, Y., and Shen, Z.: Chemical characterization and source apportionment of $\mathrm{PM}_{2.5}$ in Beijing: seasonal perspective, Atmos. Chem. Phys., 13, 7053-7074, doi:10.5194/acp-137053-2013, 2013.

Zhang, R., Li, Q., and Zhang, R.: Meteorological conditions for the persistent severe fog and haze event over eastern China in January 2013, Sci. China Ser. D, 57, 26-35, doi:10.1007/s11430-013-4774-3, 2014.

Zhao, P. S., Dong, F., He, D., Zhao, X. J., Zhang, X. L., Zhang, W. Z., Yao, Q., and Liu, H. Y.: Characteristics of concentrations and chemical compositions for PM2.5 in the region of Beijing, Tianjin, and Hebei, China, Atmos. Chem. Phys., 13, 4631-4644, doi:10.5194/acp13-4631-2013, 2013.

\section{ACPD}

$15,11111-11141,2015$

Heavy air pollution in Beijing

B. Han et al.

Title Page

Abstract

Introduction

Conclusions

References

Tables

Figures

14

$>1$

4

Back

Close

Full Screen / Esc

Printer-friendly Version

Interactive Discussion 
Table 1. Meteorological conditions of January in Beijing.

\begin{tabular}{llllll}
\hline Meteorological parameter & Temperature $\left({ }^{\circ} \mathrm{C}\right)$ & Relative humidity $(\%)$ & Atmospheric press $(\mathrm{Hpa})$ & Wind speed $\left(\mathrm{ms} \mathrm{s}^{-1}\right)$ & Calm wind frequency $(\%)$ \\
\hline Mean (range) & $-5.1(-14.0-3.8)$ & $55(18-94)$ & $1023.7(1012.8-1041.8)$ & $1.9(0-7.9)$ & 6.64 \\
\hline
\end{tabular}

ACPD

15, 11111-11141, 2015

Heavy air pollution in Beijing

B. Han et al.

Title Page

Abstract

Introduction

Conclusions References

Tables

Figures

14 $>1$

4

Back

$>$

Close

Full Screen / Esc

Printer-friendly Version

Interactive Discussion

(c) (1) 
Table 2. The detection limit of URG9000.

\begin{tabular}{lllllllll}
\hline lons & $\mathrm{Cl}^{-}$ & $\mathrm{NO}_{3}^{-}$ & $\mathrm{SO}_{4}^{2-}$ & $\mathrm{Na}^{+}$ & $\mathrm{NH}_{4}^{+}$ & $\mathrm{K}^{+}$ & $\mathrm{Mg}^{2+}$ & $\mathrm{Ca}^{2+}$ \\
\hline $\mathrm{DL}\left(\mu \mathrm{g} \mathrm{m}^{-3}\right)$ & 0.0100 & 0.0500 & 0.0400 & 0.0500 & 0.0500 & 0.0900 & 0.0600 & 0.1000 \\
\hline
\end{tabular}

ACPD

15, 11111-11141, 2015

Heavy air pollution in Beijing

B. Han et al.

Title Page

Abstract

Introduction

Conclusions References

Tables

Figures

$1<$

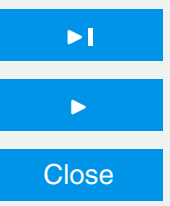

Back

Full Screen / Esc

Printer-friendly Version

Interactive Discussion 
Table 3. Descriptive statistics of ion species in January $\left(N=676, \mathrm{~g} \mathrm{~m}^{-3}\right)$.

\begin{tabular}{lllllll}
\hline Species & Mean & Median & Range & \multicolumn{3}{l}{ Percentile } \\
\cline { 5 - 7 } & & & & $25 \%$ & $50 \%$ & $75 \%$ \\
\hline $\mathrm{Cl}^{-}$ & 4.91 & 3.71 & $0.28-21.90$ & 1.69 & 3.71 & 6.96 \\
$\mathrm{NO}_{3}^{-}$ & 16.35 & 12.27 & $1.39-66.11$ & 3.94 & 12.27 & 25.71 \\
$\mathrm{SO}_{4}^{2-}$ & 23.52 & 9.14 & $0.01-179.44$ & 2.46 & 9.14 & 41.32 \\
$\mathrm{Na}^{+}$ & 2.04 & 1.93 & $0.86-8.22$ & 1.66 & 1.93 & 2.28 \\
$\mathrm{NH}_{4}^{+}$ & 10.48 & 6.25 & $0.29-165.26$ & 1.63 & 6.25 & 15.01 \\
$\mathrm{~K}^{+}$ & 1.38 & 1.02 & $0.07-9.53$ & 0.36 & 1.02 & 1.93 \\
$\mathrm{Mg}^{2+}$ & 0.71 & 0.73 & $0.13-1.04$ & 0.69 & 0.73 & 0.80 \\
$\mathrm{Ca}^{2+}$ & 1.08 & 1.15 & $0.07-2.62$ & 1.05 & 1.15 & 1.25 \\
\hline
\end{tabular}

15, 11111-11141, 2015

Heavy air pollution in Beijing

B. Han et al.

Title Page

Abstract

Introduction

Conclusions References

Tables

Figures

14 >

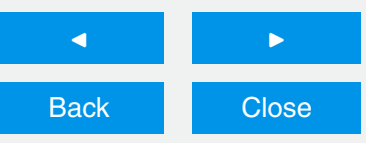

Full Screen / Esc

Printer-friendly Version

Interactive Discussion 


\section{ACPD}

\section{$15,11111-11141,2015$}

Heavy air pollution in Beijing

B. Han et al.

Table 4. Comparisons of the concentrations of ions in several studies in Beijing during winter by manual samplers $\left(\mu \mathrm{g} \mathrm{m}^{-3}\right)$.

\begin{tabular}{llllll}
\hline Studies & Sampling time & $\mathrm{SO}_{4}^{2-}$ & $\mathrm{NO}_{3}^{-}$ & $\mathrm{Cl}^{-}$ & $\mathrm{NH}_{4}^{+}$ \\
\hline He et al. (2001) & $1999-2000$ & 24.87 & 15.35 & - & 7.80 \\
Cao et al. (2012) & Jan 2003 & 20.0 & 13.1 & 2.3 & 9.4 \\
Sun et al. (2004) & $2002-2003$ & 27.80 & 16.60 & 6.77 & 15.50 \\
Wang et al. (2005) & $2001-2003$ & 20.96 & 12.29 & 5.28 & 10.64 \\
Okuda et al. (2013) & $2008-2009$ & 24.09 & 18.71 & 8.06 & 12.26 \\
Zhao et al. (2013) & $2009-2010$ & 14.23 & 17.09 & - & 5.21 \\
This study & Jan 2013 & 23.52 & 16.35 & 4.91 & 10.48 \\
\hline
\end{tabular}

Title Page

Abstract

Conclusions

Tables

14

4

Back

Full Screen / Esc

Printer-friendly Version

Interactive Discussion 
Table 5. Comparisons of the concentrations of ions between this study and a simultaneous study $\left(\mu \mathrm{gm}^{-3}\right)$.

\begin{tabular}{lllll}
\hline & \multicolumn{2}{l}{ Huang et al. (2014) } & \multicolumn{2}{l}{ This study } \\
\cline { 2 - 5 } $\mathrm{Cl}^{-}$ & $4-9$ Jan & 10-15 Jan & 4-9 Jan & $10-15$ Jan \\
2.35 & 7.57 & 5.35 & 24.36 \\
\hline $\mathrm{NO}_{3}^{-}$ & 6.88 & 28.58 & 3.75 & 47.52 \\
$\mathrm{SO}_{4}^{2-}$ & 7.81 & 44.32 & 1.78 & 2.56 \\
$\mathrm{Na}^{+}$ & 0.57 & 0.95 & 1.76 & 16.28 \\
$\mathrm{NH}_{4}^{+}$ & 4.34 & 14.64 & 0.49 & 2.45 \\
$\mathrm{~K}^{+}$ & 0.81 & 4.15 & 0.73 & 0.78 \\
$\mathrm{Mg}^{2+}$ & 0.23 & 0.23 & 1.25 & 1.28 \\
$\mathrm{Ca}^{2+}$ & 0.51 & 0.44 & & \\
\hline
\end{tabular}

ACPD

$15,11111-11141,2015$

Heavy air pollution in Beijing

B. Han et al.

Title Page

Abstract

Introduction

Conclusions

References

Tables

Figures

14

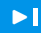

4

Back

Close

Full Screen / Esc

Printer-friendly Version

Interactive Discussion

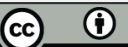


Table 6. The correlation coefficients $(r)$ and the linear regression equations between major ions.

\begin{tabular}{lllll}
\hline & $\mathrm{Cl}^{-}$ & $\mathrm{NO}_{3}^{-}$ & $\mathrm{SO}_{4}^{2-}$ & \\
\hline $\mathrm{Na}^{+}$ & $\mathbf{0 . 9 0 0}$ & $\mathbf{0 . 8 2 7}$ & $\mathbf{0 . 8 1 8}$ & \\
$\mathrm{NH}_{4}^{+}$ & $\mathbf{0 . 8 9 5}$ & $\mathbf{0 . 9 7 1}$ & $\mathbf{0 . 9 7 0}$ & $\left(\mathrm{NH}_{4}^{+}\right)=1.33 \times\left(\mathrm{SO}_{4}^{2-}\right)-0.01$ \\
$\mathrm{~K}^{+}$ & $\mathbf{0 . 8 9 2}$ & $\mathbf{0 . 9 0 3}$ & $\mathbf{0 . 9 2 4}$ & $\left(\mathrm{NH}_{4}^{+}\right)=3.40 \times\left(\mathrm{NO}_{3}^{-}\right)-0.25$ \\
$\mathrm{Mg}^{2+}$ & 0.182 & 0.021 & 0.071 & $\left(\mathrm{NH}_{4}^{+}\right)=0.99 \times\left[\left(\mathrm{SO}_{4}^{2-}\right)+\left(\mathrm{NO}_{3}^{-}\right)\right]-0.01$ \\
$\mathrm{Ca}^{2+}$ & 0.075 & -0.170 & -0.145 & \\
\hline
\end{tabular}

Note: bold figures indicates that the correlation coefficient is higher than 0.80 .

$15,11111-11141,2015$

Heavy air pollution in Beijing

B. Han et al.

Title Page

Abstract

Introduction

Conclusions

References

Tables

Figures

14 $>1$

4

Back

Close

Full Screen / Esc

Printer-friendly Version

Interactive Discussion 


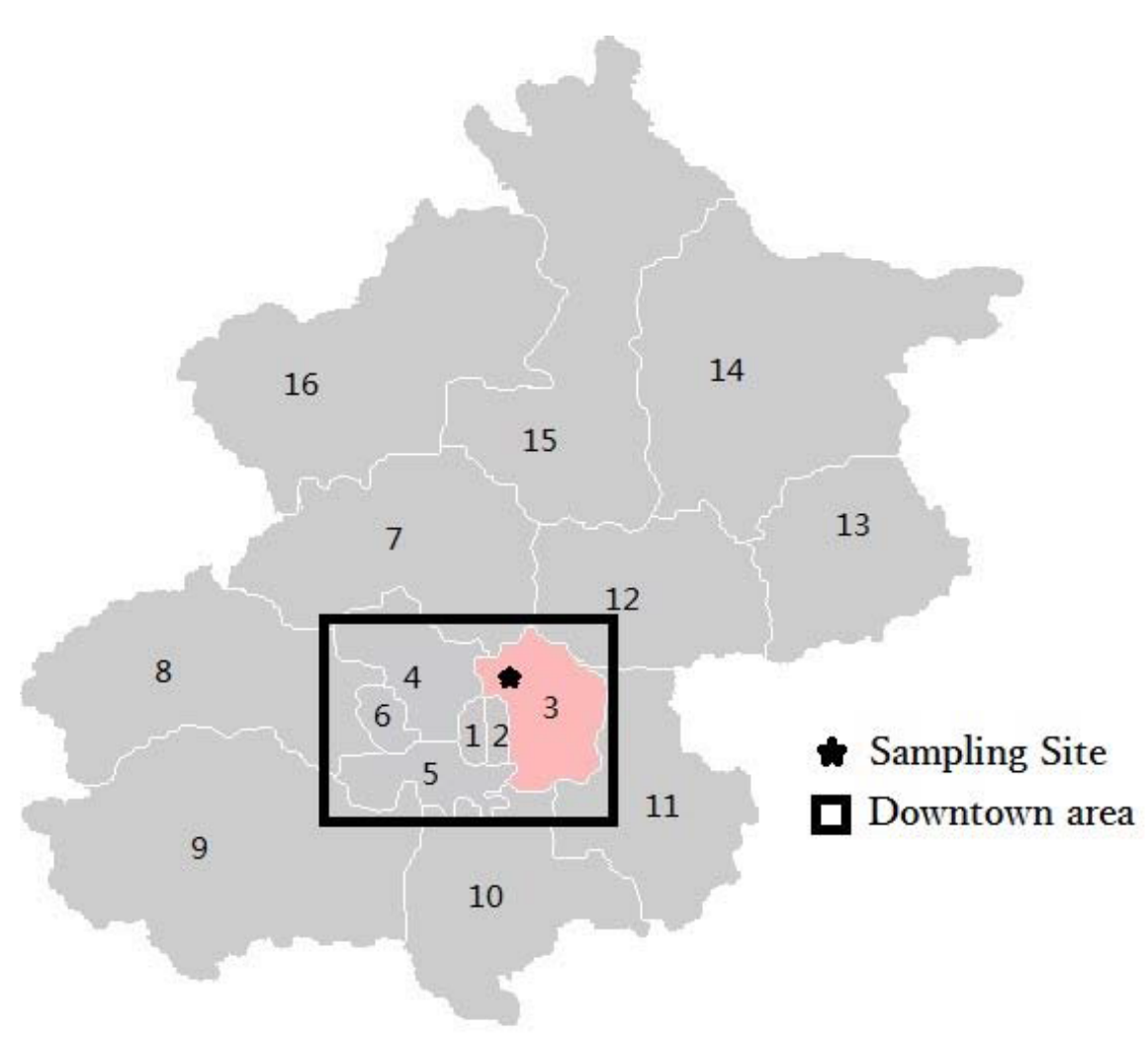

\section{ACPD}

15, 11111-11141, 2015

Heavy air pollution in Beijing

B. Han et al.

\section{Title Page}

\section{Abstract}

Introduction

Conclusions

References

Tables

Figures

14

$\rightarrow$

4

Back

Close

Full Screen / Esc

Printer-friendly Version

Interactive Discussion

Figure 1. Location of sampling site in Beijing ((1) Xicheng District; (2) Dongcheng District; (3) Chaoyang District; (4) Haidian District; (5) Fengtai District; (6) Shijingshan District; (7) Changping District; (8) Mentougou District; (9) Fangshan District; (10) Daxing District; (11) Tongzhou District; (12) Shunyi District; (13) Pinggu District; (14) Miyun District; (15) Huairou District; (16) Yanqin District). 


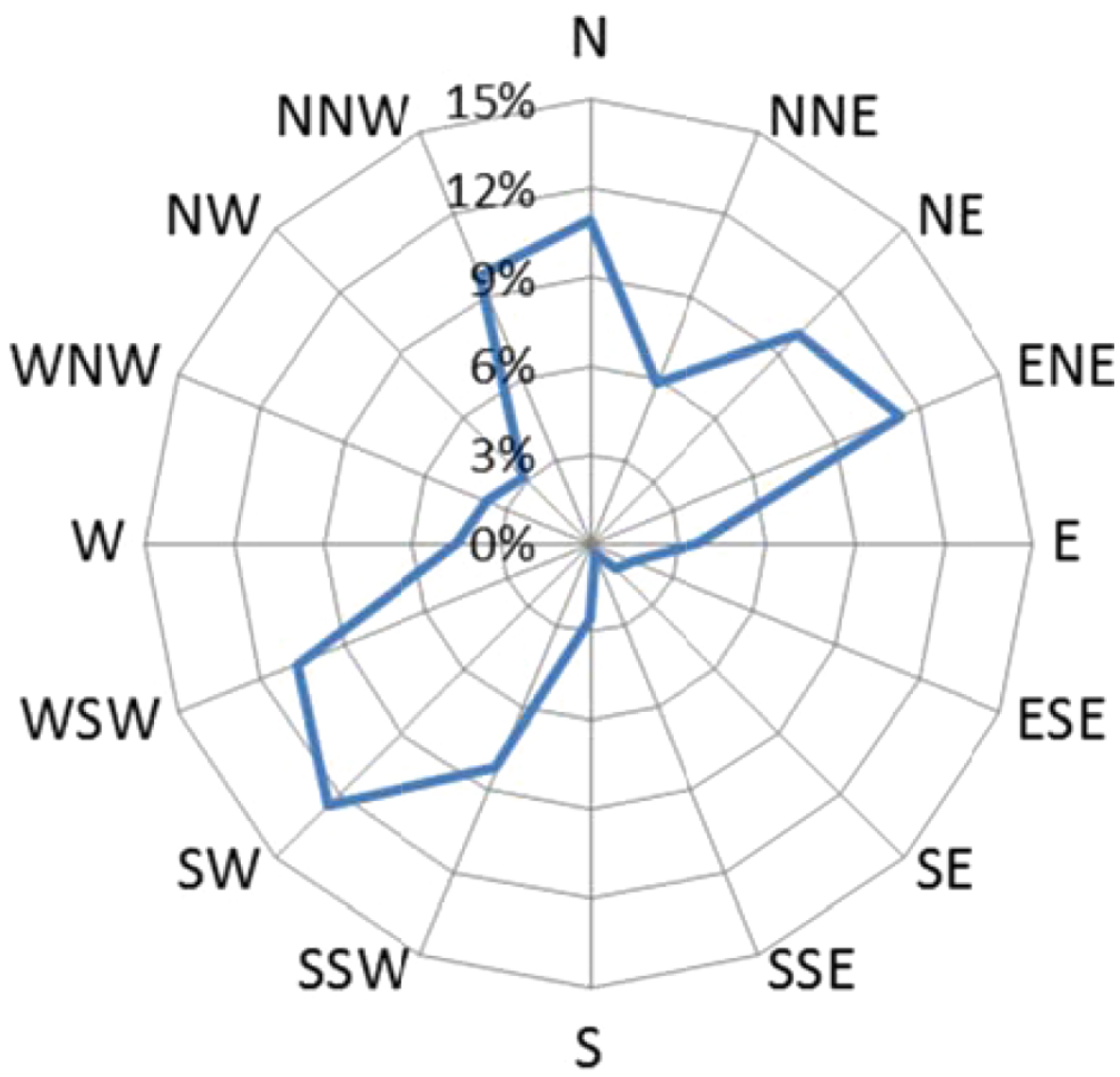

\section{ACPD}

15, 11111-11141, 2015

Heavy air pollution in Beijing

B. Han et al.

Title Page

Abstract

Conclusions

Tables

14

Back

Full Screen / Esc

Printer-friendly Version

Interactive Discussion

Figure 2. Wind roses of January in Beijing. 


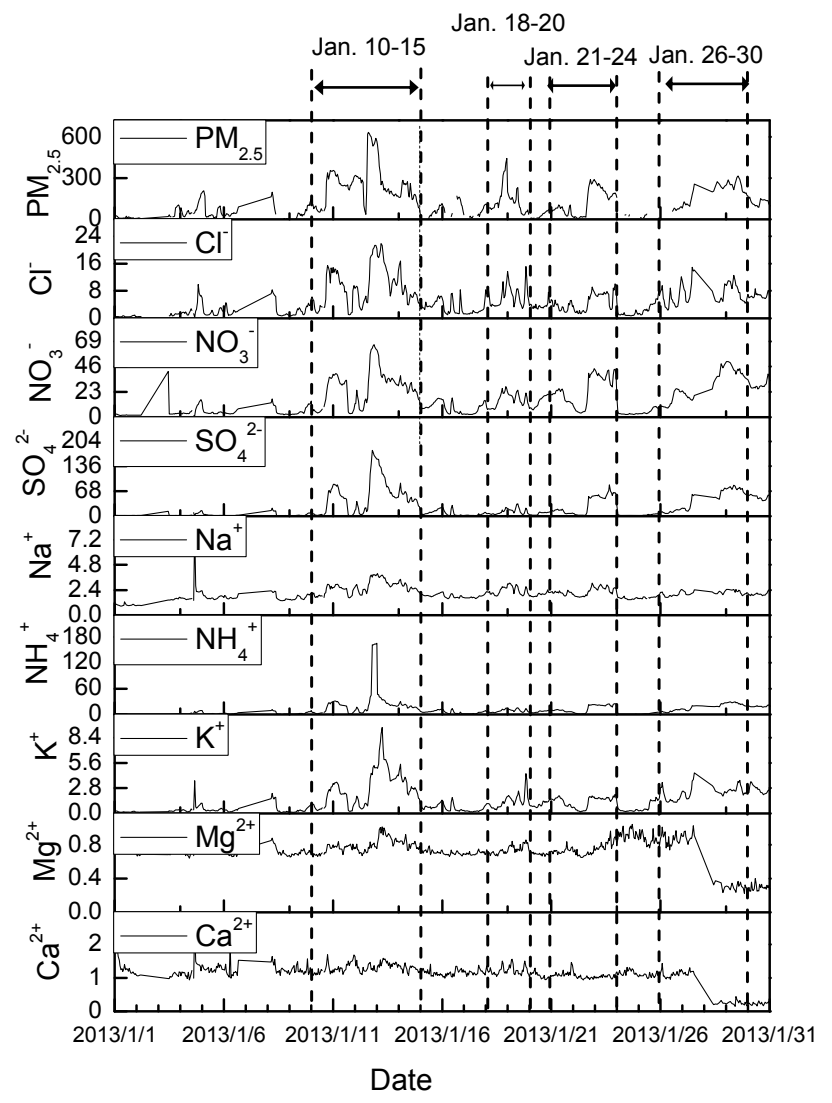

Figure 3. Variation of $\mathrm{PM}_{2.5}$ and ions concentrations in the sampling site in January 2013 (the peak period of $\mathrm{PM}_{2.5}$ are marked between the dote lines).

\section{ACPD}

\section{$15,11111-11141,2015$}

Heavy air pollution in Beijing

\section{B. Han et al.}

Title Page

\section{Abstract}

Introduction

Conclusions

References

Tables

Figures

14

DI

4

Back

Close

\section{Full Screen / Esc}

Printer-friendly Version

Interactive Discussion 


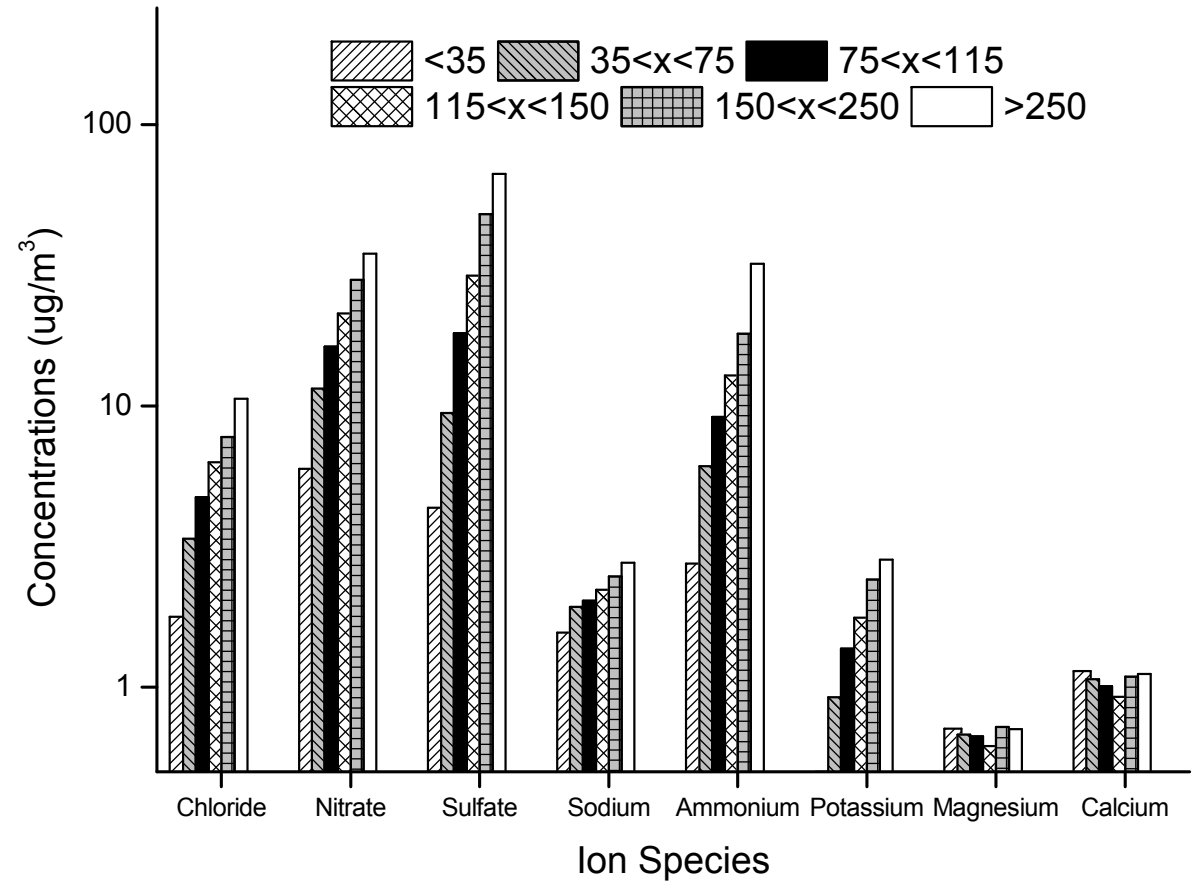

Heavy air pollution in Beijing

B. Han et al.

Title Page

Abstract

Introduction

Conclusions References

Tables

Figures

14

$>1$

4

Back

Close

Full Screen / Esc

Printer-friendly Version

Figure 4. Concentrations of ion species at different $\mathrm{PM}_{2.5}$ range.

Interactive Discussion

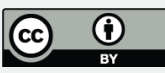




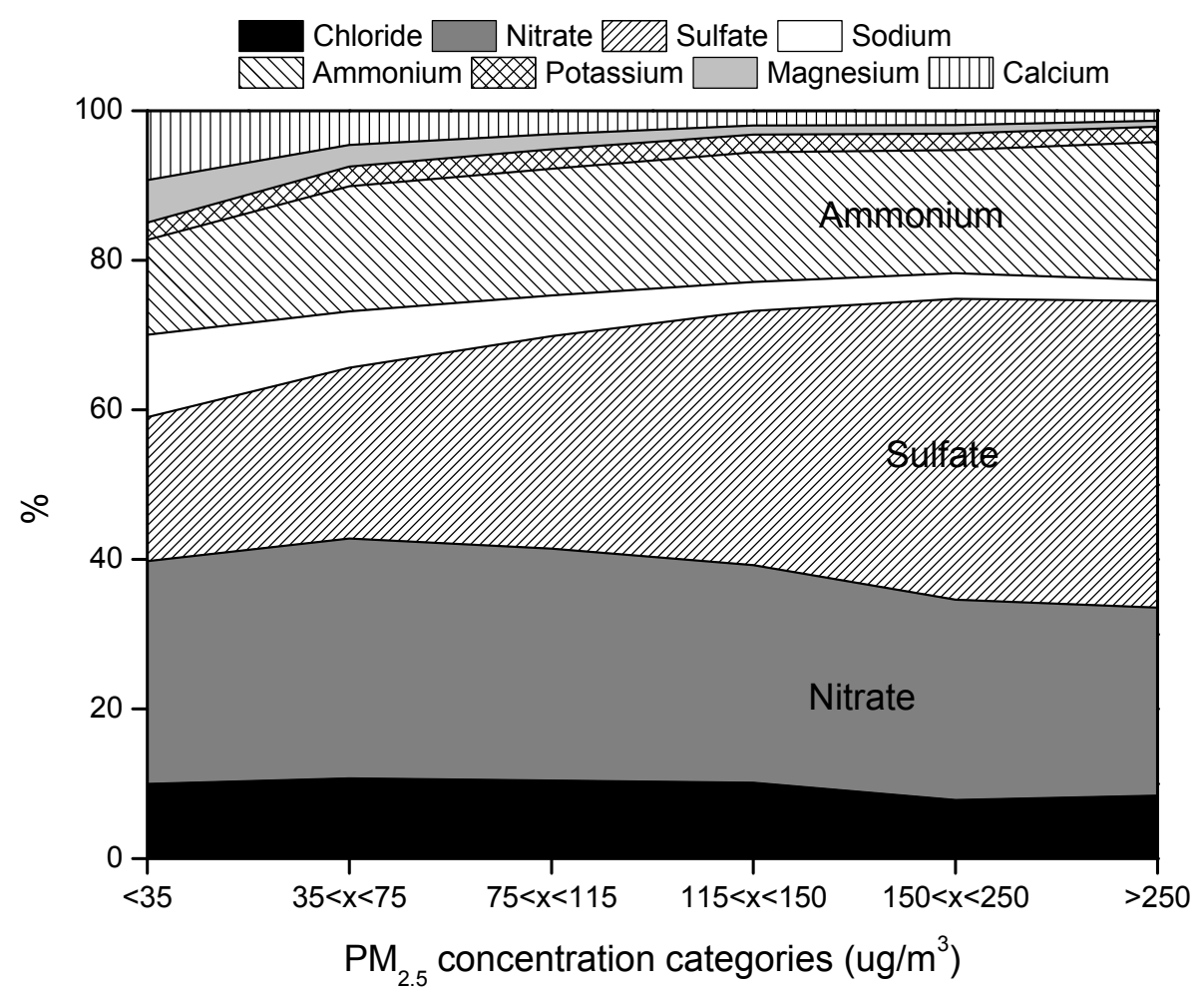

15, 11111-11141, 2015

Heavy air pollution in Beijing

B. Han et al.

Title Page

Abstract

Introduction

Conclusions

References

Tables

Figures

14

$\rightarrow$

4

Back

$>$

Full Screen / Esc

Printer-friendly Version

Figure 5. Percentage of ion species in total ions at different $\mathrm{PM}_{2.5}$ range.

Interactive Discussion

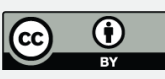




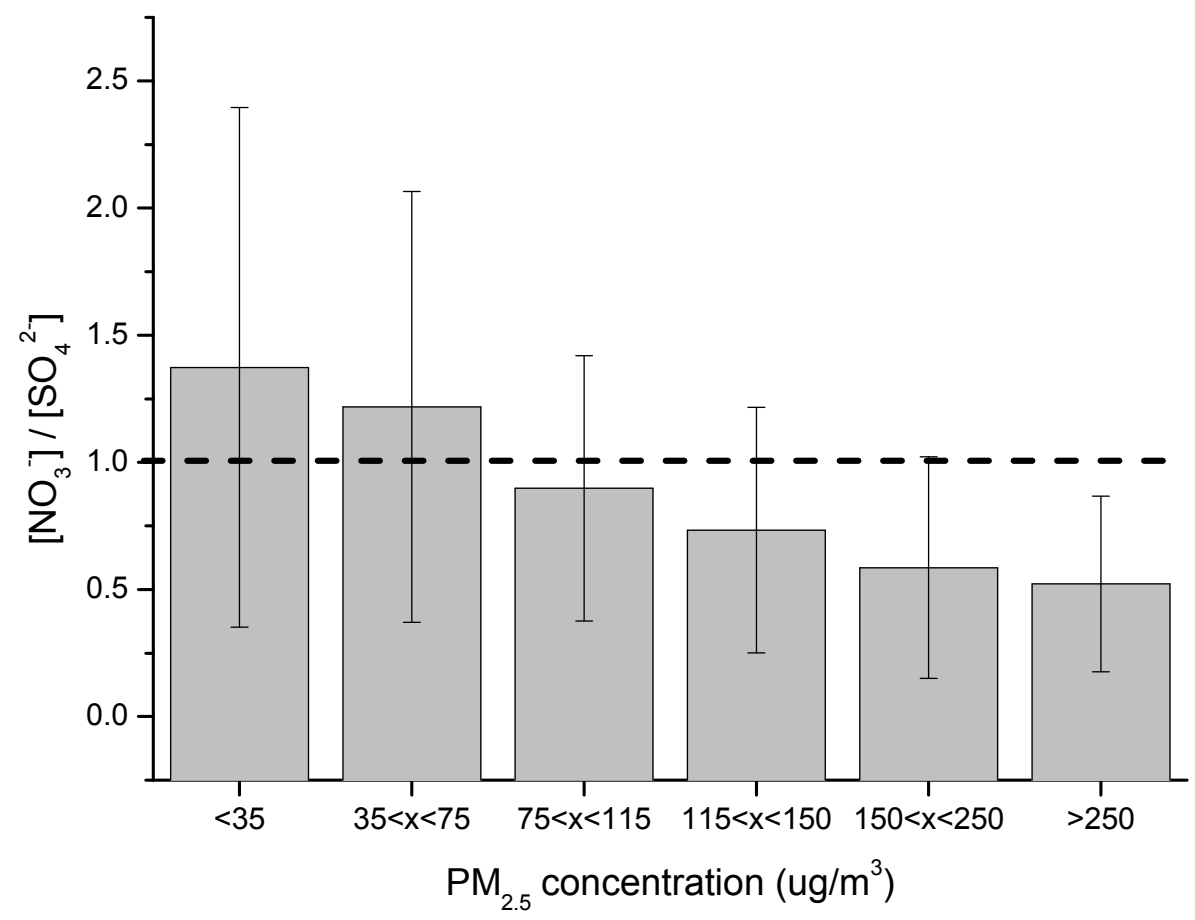

Heavy air pollution in Beijing

B. Han et al.

Title Page

Abstract

Introduction

Conclusions

References

Tables

Figures

14 $>1$

4

Back

Close

Full Screen / Esc

Printer-friendly Version

Figure 6. Ratio of $\left[\mathrm{NO}_{3}^{-}\right] /\left[\mathrm{SO}_{4}^{2-}\right]$ at different $\mathrm{PM}_{2.5}$ concentration ranges.

Interactive Discussion 


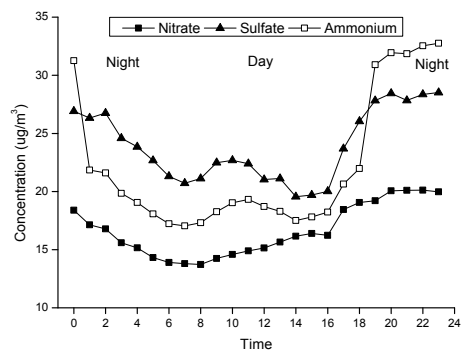

\section{ACPD}

\section{5, 11111-11141, 2015}

Heavy air pollution in Beijing

B. Han et al.

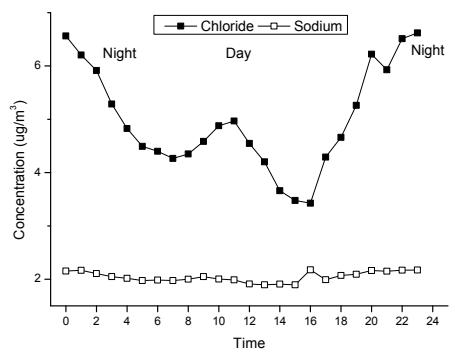

Page

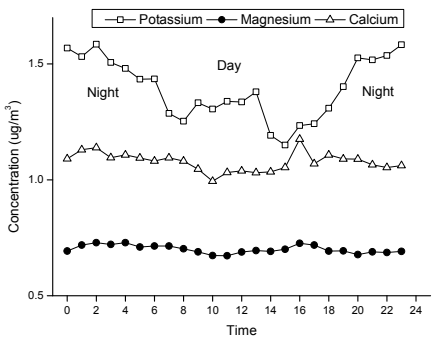

Abstract

Introduction

Conclusions

References

Tables

Figures

14

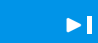

4

Back

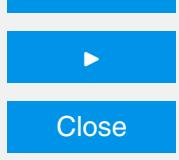

Full Screen / Esc

Printer-friendly Version

Interactive Discussion

Figure 7. Diurnal variations of ion species. 

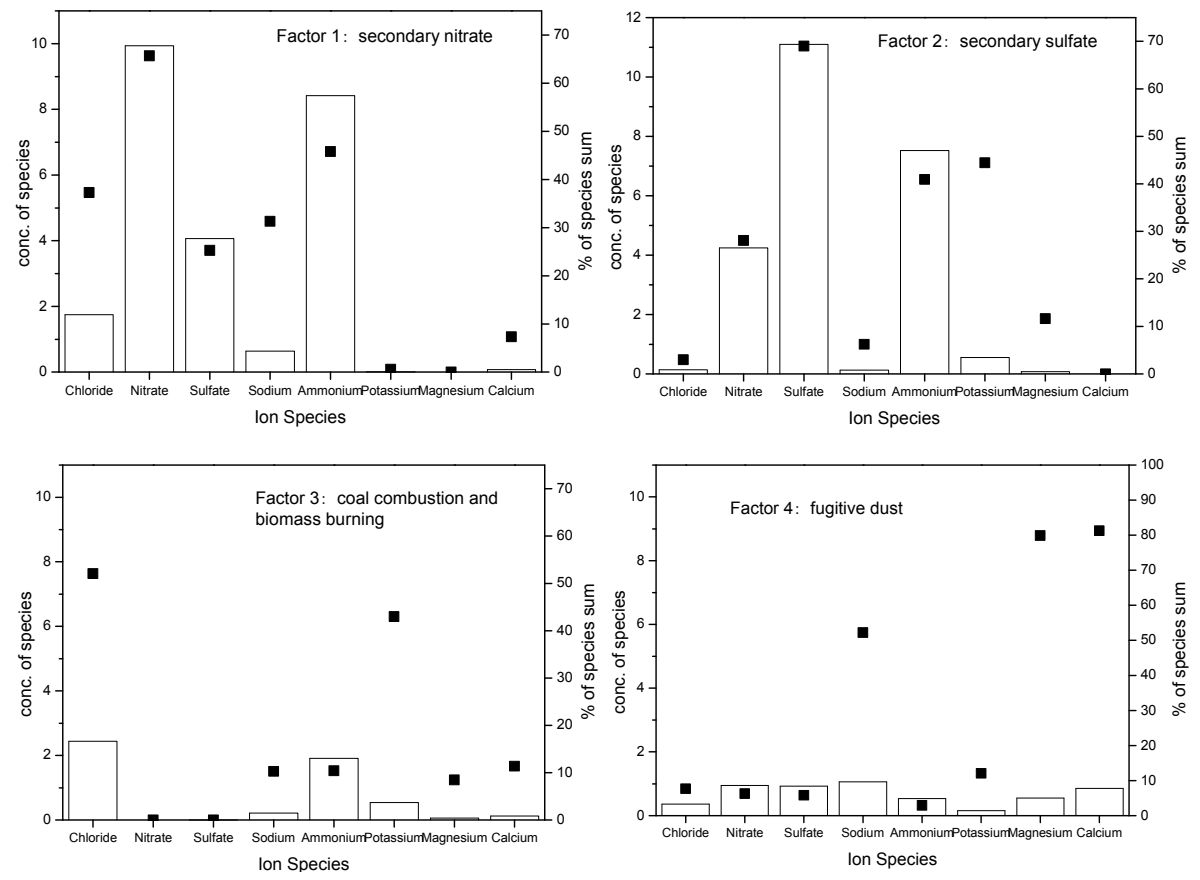

Figure 8. Factor profiles of $\mathrm{PM}_{2.5}$ bound ion species in the urban site of Beijing.
ACPD

15, 11111-11141, 2015

Heavy air pollution in Beijing

\section{B. Han et al.}

Title Page

Abstract

Introduction

Conclusions References

Tables

Figures

14

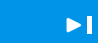

4

Back

Close

\section{Full Screen / Esc}

Printer-friendly Version

Interactive Discussion 


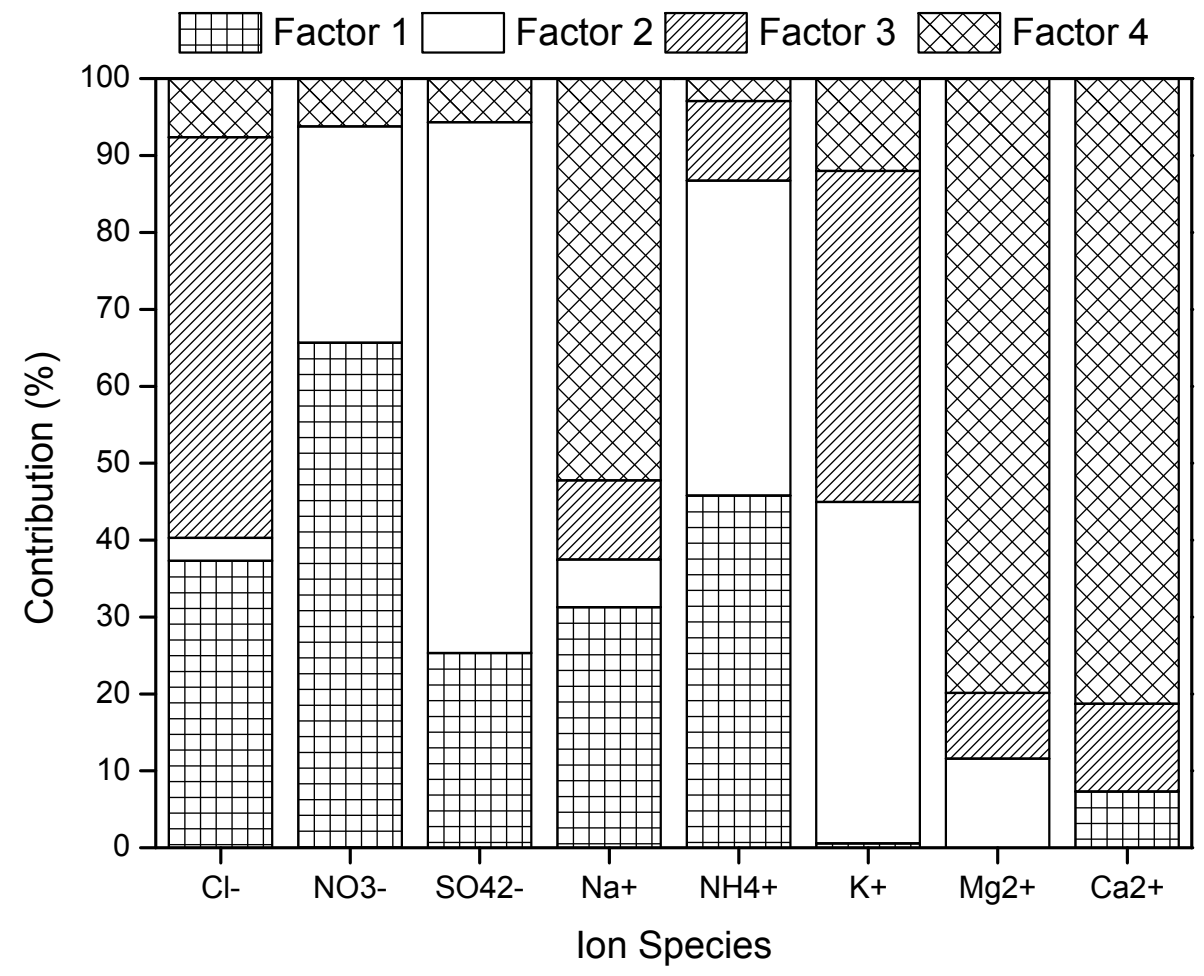

15, 11111-11141, 2015

Heavy air pollution in Beijing

B. Han et al.

Title Page

Abstract

Introduction

Conclusions

References

Tables

Figures

1

4

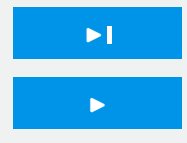

Back

Close

Full Screen / Esc

Printer-friendly Version

Interactive Discussion

Figure 9. The contributions of factors to the ion species.

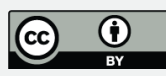

